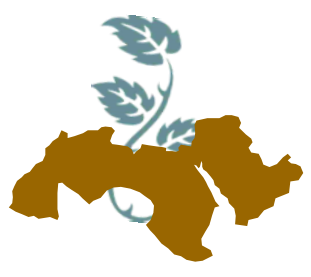

\title{
EFFECT OF RESTRICTED FEEDING PERIODS DURING LATE PREGNANCY AND EARLY LACTATION ON THE PRODUCTIVE AND REPRODUCTIVE PERFORMANCES OF THE DROMEDARY SHE -CAMEL
}

\author{
Amal A. Othman'; H.M.A. El-Sayed ${ }^{2}$; M.R.E. Anous ${ }^{2}$ and A.E.B. Zeidan ${ }^{3}$ \\ 1- Camel Breeding Research Dept., Animal Production Research Institute, Ministry of Agric., \\ Dokki, Giza, Egypt \\ 2- Animal Productions Dept., Fac. of Agric., Ain Shams Univ., Cairo, Egypt \\ 3- Cattle Breeding Research Dept., Animal Production Research Institute, Ministry of Agric., \\ Dokki, Giza, Egypt
}

Keywords: Camels, Feed restriction, Digestibility, Camel calves growth

\section{ABSTRACT}

The present study aimed to justify the effects of restricted feeding periods during last month of pregnancy and initiation of lactation on growth rate of Maghrebi she-camel and their offsprings. Sixteen pregnant she- camels with an average body weight $512.74 \mathrm{~kg}$ were divided randomly into three groups. The first group (G1) was fed $100 \%$ of their daily requirements concentrates. The second group (G2) was offered $75 \%$ of their daily requirement of concentrates after delivery for one month, while the third group (G3) was fed on $75 \%$ of their daily of concentrate requirements for two months (one month pre and another one post-partum). New born calves were divided after one month of lactation to four groups as following; calves born G1 dams were divided randomly to two subgroups. The first one (G11) suckled their dams naturally, while the other (G12) was artificial reared on a milk mixture $(50 \%$ natural camel milk and $50 \%$ cattle milk replacer). Calves born to $\mathrm{G} 2$ and $\mathrm{G} 3$ dams were artificial reared on a mixture $50 \%$ natural camel milk and $50 \%$ cattle milk replacer. Results obtained showed that she-camels of G1 gained insignificant more live body weight than that of G3 during the pre-calving period 49.09 vs. $42.05 \mathrm{~kg}$, respectively. There were insignificant differences among the 3 groups in calves birth weight 30.44 , 32.8 and $29.73 \mathrm{~kg}$, respectively. During lactation period, she-camels of $\mathrm{G} 1$ produced insignificantly more daily milk in compare with the corresponding she-camels of G2 and G3 (3.78 liter vs. 3.32 and 3.4 liter/ animal), respectively. She-camel of G3 lost significantly $(P<0.05)$ more LBW from the beginning of the experiment to the end of the study in compare with both of $\mathrm{G} 1$ and $\mathrm{G} 2$ she-camels. Calves of one month of age and born to G1 dams indicate faster $(P<0.05)$ daily gain $(0.326 \mathrm{~kg} / \mathrm{h} /$ day) than those to both of $\mathrm{G} 2$ and $\mathrm{G} 3$ dams. Three months old age calves of different groups, indicated nearly similar growth, regardless of their dams feed restriction and type of calves rearing (natural vs. artificial). Data obtained showed also that neither she-camels feed restriction practice nor type of calves rearing have any significant effect on either calves daily gain or dams final LBW after 3 months of treatments.

\section{INTRODUCTION}

The relationship between feed intake and milk production during pregnancy period of she-camel and calf birth weight are considered of practical importance in camel farming system. Indeed, the prenatal growth trajectory is sensitive to the direct and indirect effects of maternal dietary intake from the earliest stages of embryonic life, when the nutrient requirements for concept growth are negligible (Robinsonetal., 1995). Lodge et al (1975) postulated that feed restriction during pre-partum may act as a stimulant to improve feed intake after calving which would be desirable as the efficiency 
of conversion of nutrients to milk, has been shown to be better when the nutrients are directly converted to milk in a dairy cow than when they are routed through body energy reserves.

Guerouali and Wardeh (2000) referred that restricted feeding in camel at levels of $40 \%, 60 \%$, $80 \%$ and $100 \%$ as dry matter of diet consists of $50 \%$ barley grain, $17 \%$ sunflower meal and $33 \%$ ground straw, the Dry matter digestibility increase in camel with the increase of level of intake. While, Afaf, (2007) found that feed restriction periods to (30, 60, 90 days) showed insignificantly effect on digestibility of most nutrients had happened except crude protein (CP) which was decreased by increase of the restricted period.

Therefore, the present study aimed to define the effect of restricted feeding period during late pregnancy and early lactation on productive and reproductive traits of the Maghrebi she-camels.

\section{MATERIALS AND METHODS}

\section{1- Experimental design}

Three restricted feeding periods were evaluated in this study using three groups of 16 Maghrebi she-camels. The first group (G1) received $100 \%$ of feeding requirements according to recommendations of Animal Production Research institute for pregnant and dairy camel from the beginning to the end of the experiment. She-camels in groups (G2) and (G3) were given restricted concentrate feeding rations (CFR) and ad libitum of roughage. She- camels in group (G2) were given normal feeding before delivery and $75 \%$ of concentrate requirements for one month after delivery. The third group (G3) was given $75 \%$ of concentrate feeding requirements for two months, one month before and one month after delivery.

\section{2-Experimental Animals}

Sixteen pregnant Maghrebi she-camels (Camelus dromedarus) with average live body weight (LBW) $512.74 \mathrm{~kg}$ and parity (2-5) were randomly assigned according to average body live weight and parity into three groups 6 animals for G1, 5 animals for each G2 and G3. The average body weight was routinely recorded during the last three months of gestation, at the delivery and thereafter during three months of post-partum. Newborn calves of the dams groups were also weighted at birth and thereafter during 7 months post-calving.

\section{3- Experimental rations}

The experimental ration consisted of concentrate feed mixture, wheat straw and berseem hay. The concentrate feed mixture (CFM) composed of $25 \%$ wheat bran, $25 \%$ yellow corn, $9 \%$ uncorticated cotton seed meal, $20 \%$ barley, $15 \%$ rice brain, $3 \%$ molasses, $2 \%$ premix and $1 \%$ common salt. The chemical composition of CFM, rice straw and berseem hay are presented in Table (1).

Table 1. Chemical compositions of the experimental rations ingredients and ration used feeding of Maghrebi she- camel during pregnancy and lactation (on dry matter basis)

\begin{tabular}{|l|c|c|c|c|}
\hline Nutrients & $\begin{array}{c}\text { CFM (concentrate } \\
\text { feed mixture) }\end{array}$ & $\begin{array}{c}\text { BH } \\
\text { (berseem } \\
\text { hay) }\end{array}$ & $\begin{array}{c}\text { RS (rice } \\
\text { straw) }\end{array}$ & $\begin{array}{c}\text { Chemical } \\
\text { composition of } \\
\text { experimental ration }\end{array}$ \\
\hline Dry matter \% & 90.8 & 92.8 & 89.0 & 90.4 \\
Organic matter \% & 89.3 & 92.4 & 85.0 & 88.6 \\
Crude Fiber \% & 13.0 & 30.5 & 44.3 & 27.5 \\
Crude protein \% & 12.9 & 11.3 & 3.5 & 10.8 \\
Ether extract \% & 3.6 & 3.2 & 1.7 & 2.7 \\
Nitrogen free extract \% & 59.8 & 47.4 & 35.5 & 47.6 \\
Ash \% & 10.7 & 7.6 & 15.0 & 11.4 \\
\hline
\end{tabular}

\section{3- Digestibility trials}

Two digestibility trails were conducted. The first one was carried out at the end of the first restricted feeding period five days before delivery while, the second trail was carried out at the end of restriction after delivery 30 days. During the digestion trail, animals were fed their daily allowance according to the experimental design assigned for each group over the feeding trail. About $200 \mathrm{~g}$ fecal samples 
were taken during the collection period for three consecutive days. The daily samples of feces for each animal were frozen immediately after collection at -20 until the end of collection period. Composite samples were prepared and dried in a forced air oven at $60{ }^{\circ} \mathrm{C}$ for 72 hours, then ground and kept at room temperature until chemical analysis. Nutrients digestibility were determined using Acid Insoluble Ash (AIA) as internal indicator according to Reid et al (1950).

$X=100-100$ (Percent of indicator in feed $\div$ percent of nutrient in feed) $\times$ (Percent of nutrients in feces $\div$ Percent of indicator in feces), where $X$ : equal nutrient digestibility.

\section{Chemical analysis}

Feed and feces were prepared for proximate analysis according to A.O.A.C (1990). Acid insoluble Ash (AIA) was analyzed according to Van Keulen and Young (1977).

\section{Suckling routine}

Newborn calves were suckling freely from dams up to one month old then separated from their dams and suckled twice a day, thereafter. Calves born from G1 group were divided into two sub-groups G11 (which suckled natural from their dams), while $\mathrm{C} 12$ (which artificial reared on a mixture of $50 \%$ natural milk and $50 \%$ reconsistituent cattle milk powder) on the other hand calves born to both groups G2 and G3 dams were suckled artificial reared on the same milk mixture like of that G12 calves. Calves of different feed restriction groups and regardless of type of rearing were weaned late at 6 months old age.

\section{Milk preparation for artificial rearing}

Cattle milk powder used in artificial rearing was prepared by dissolving one $\mathrm{kg}$ of cow milk powder in $8 \mathrm{~kg}$ of warm water $\left(50{ }^{\circ} \mathrm{C}\right)(1: 8$ dilution rate) and mixed well, then cooled to about $37^{\circ} \mathrm{C}$ and mixed well with camel milk with ratio $1: 1$. The milk was given to calves in I liter nursing nippled bottle. Calves were adapted to consume daily of this mixture until weaning. New-Zealand Cow milk powder used in artificial rearing of newborn calves consisted of $2.8 \%$ moisture, $24.0 \%$ protein, $28.5 \%$ fat, $5.7 \%$ mineral and $39.0 \%$ lactose.

\section{Statistical analysis}

Data were statistically analyzed according to Statistical Analysis System (SAS, 2006). The differences among the means of three groups were checked by Duncan's multiple range test to test the significance of differences among means. Data of digestibility and body weight changes were analyzed according to the following model.

$Y_{i j}=U+T_{i}+e_{i j}$

$\mathrm{Y}=$ an observation (as Total milk yield)

$\mathrm{U}=$ is overall mean

$\mathrm{T}=$ effect of restricted feeding

$\mathrm{e}=$ residual error

\section{RESULTS AND DISCUSIONS}

\section{1- Digestion coefficients}

The data of Table (2) showed the effect of feed restriction in Maghrebi she-camel on nutrients digestibility before and after calving and the mean value. The dry matter digestibility not affected by feed restriction. The data clearly showed that slightly insignificant decrease in DM digestibility pre-calving were recorded for G3 compared to G1 and $\mathrm{G} 2$ and no significant differences were recorded among three groups post-calving and the mean value. In this connection Nagpal and Patil (2012) found no significant differences in DM digestibility in dromedary camel which had different energy levels. While, Filali and Guerouali (1994) reported that DM digestibility was $56.2 \%$ of one hump camels fed on the restricted ration at maintenance energy. Khorchani et al (1992) reported that dry matter digestibility (DMD) ranged from $50-60 \%$ in the stall-feeding (intensive system) camel and that was similar to that reported by Afaf (2007) who found that dry matter digestibility(DMD) were ranged between 51.38 to $55.89 \%$ for growing camel fed on restricted ration consists of $0.5 \%$ of body weight as berseem. Safinaze et al (2012) found that when camel fed iso-nitrgenous rations and different levels of energy $(100,120,140$ and $160 \mathrm{k}$ calorie $/ \mathrm{kg}^{0.75}$ ) of dry matter digestibility (DMD) was 56.33, 62.78, 64.08, and 68.99 (\%), respectively. These results are disagreement with those of Guerouali and Wardeh (2000) who showed that the digestibility (\%) of the restricted feeding to camel at levels of $40 \%, 60 \%, 80 \%$ and $100 \%$ as dry matter was $57.9,62.4,63.5$ and $69.6(\%)$, respectively of diet consisted of $50 \%$ barley grain, $17 \%$ sunflower meal and $33 \%$ ground straw and they found that the Dry matter digestibility was increase in camel with the increase of intake level. 
The mean values of $\mathrm{OM}$ and CF digestibility pre-calving period ranged from 58.5 to $60.75 \%$ and 50.7 to $53.25 \%$, respectively with insignificant differences. While, post-partum OM digestibility there were significant $(P<0.05)$ decreased in OM digestibility in group (G3) post-partum. The values of CF digestibility post-partum and the mean values of CF pre and post-partum had no significant differences. The mean values of $\mathrm{OM}$ digestibility pre and post -partum showed significant $(P<0.05)$ decreased in restricted group (G3). Results revealed that restricted periods had negative effects at this level of intake on OM digestibility and no effect on CF digestibility. This in agreement with Nagpal and Patil (2012) who found that an increase in OM digestibility with increase the level of energy from $50-60 \%$ and found that insignificant digestibility in CF in dairy dromedary camel. Abdouli and Kraiem (1990) found that apparent digestibility of DM, OM and CF were 55, 58 and $65 \%$ for dromedary camel fed on diet containing wheat straw ad libitum with concentrate restricted to $0.5 \% \mathrm{~kg} / \mathrm{day}$.

The mean values of $\mathrm{CP}, \mathrm{EE}$, and NEF digestibility in pre-partum period for three treatments groups were ranged from 47.87 to $52.95 \% ; 58.17$ to $62.22 \%$ and 63.83 to $70.23 \%$, respectively in (Table, 2). There were insignificant differences in $\mathrm{CP}$ and EE digestibility among groups while, the value of NFE digestibility was significant decreased in group (G3). Post-partum digestibilites for CP, EE and NFE were ranged 50.57 - 53.8, 62.18- 62.96 and $64.69-64.91 \%$, respectively with insignificant differences in $\mathrm{CP}$ and EE digestibility while, NFE digestibility had significant $(P<0.05)$ decreased in group (G3). The mean values of CP, EE and NFE digestibilities (Table 2) showed the same pattern.

Results referred to restricted feeding periods had insignificant effect on CP and EE digestibility while, had significant effect on NFE digestibility and this data in agreement with Nagpal and Patil (2012) found that an increase in NFE with increases in energy level in dromedary dairy camel. The range of $\mathrm{CP}$ digestibility more than reported by Afaf (2007) who fed growing camel restricted ration consisted of Berseem hay at $0.5 \%$ of live body weight with ad libtium wheat straw and found that CP digestibility was 43.87 and 38.36 and 20.55 for periods 30, 60 and 90 days, respectively and Abdouli and Kraiem (1990) found that CP digestibility was $42 \%$ in dromedary camel fed on diet containing wheat straw ad libitum with concentrate restricted to $0.5 \mathrm{~kg} /$ day.
Total digestible nutrients (TDN \%) values (Table 2) were 66.9 in Groups G1 and G2 while, G3 was $61.9 \%$. Digestible crude protein (DCP) prepartum for she-camels were $8.82 \%$ for groups G1 and G2, while it was $7.88 \%$ for G3. These values were higher than those founded by Safinaze (2012) she found that when camels were fed isonitrgenous rations but different levels of energy $\left(100,120,140\right.$ and $160 \mathrm{k}$ calorie $\left./ \mathrm{kg}^{0.75}\right)$ during late gestation. Results obtained revealed that ration nutritive valued were $4.79 \%$ DCP and TDN $52.38 \%$ may feed to pregnant dromedary female camels during the late pregnancy.

However, Digestible crude protein (DCP) values were $8.98 \%$ for group G1 and $8.1 \%$ for groups G2 and G3, respectively. Total nutrients digestibility (TDN \%) post-partum was 67.62 for groups G1 while, group G2 and G3 were 64.05, respectively.

\section{2- Growth performance of the Maghrebian she- camel during experimental period}

Data of growth performance in term of Initial live body weight of she-camels were 502.29, 511.20 and $524.75 \mathrm{~kg}$ for groups G1, G2 and G3, respectively and there were insignificant differences in live body weight among groups. Before calving live body weight of she-camels were $551.38,559.60$ and $566.8 \mathrm{~kg}$ for G1, G2 and G3 groups, respectively without significant differences.

Results in (Table 3) pointed out to gradual increase in LBW of she-camels during the last three months of gestation.

In the present study, body weight changes of she-camels were segmented into three stages; the first one from the start of the experiment to just before calving and the second stage was the difference in weights of she-camels pre calving and post- calving as showen in (Table 3 ). The third stage covered changes in live body weights from start to the end of experiment (Table 4). Results revealed that changes in She- camels weight from start of the experiment to the pre-calving period for groups G1, G2 and G3 were $(49.09,48.4$ and $42.05 \mathrm{~kg}$ ), respectively, however differences among groups were insignificantly. These results were mainly due to that groups $\mathrm{G} 1$ and $\mathrm{G} 2$ had more DM and TDN intake than G3 before calving. In this connection Khan et al (2002) who carried out an experiment on crossbred cows which had a restricted concentrate and ad libitum roughage or ad libitum feeding during last terminator of pregnancy, they found that cow fed the ad libitum system were gained more weight significantly than of restricted feeding group. 
Table 2. Effect of feed restriction in Maghrebi she-camel on nutrient digestibility before and after calving and mean value

\begin{tabular}{|c|c|c|c|c|c|c|c|c|c|}
\hline \multirow{3}{*}{ Item } & \multicolumn{9}{|c|}{ Experimental groups } \\
\hline & \multicolumn{2}{|c|}{ G1 } & \multirow{2}{*}{ Mean } & \multicolumn{2}{|c|}{ G2 } & \multirow{2}{*}{ Mean } & \multicolumn{2}{|c|}{ G3 } & \multirow{2}{*}{ Mean } \\
\hline & Before & after & & Before & After & & Before & After & \\
\hline $\mathrm{DM}$ & $\begin{array}{c}54.40^{\mathrm{a}} \\
\pm 0.63\end{array}$ & $\begin{array}{l}56.21^{\mathrm{a}} \\
\pm 0.57\end{array}$ & $55.35^{\mathrm{a}} \pm 0.61$ & $\begin{array}{l}53.54^{\mathrm{a}} \\
\pm 1.15\end{array}$ & $\begin{array}{l}56.00^{\mathrm{a}} \\
\pm 0.86\end{array}$ & $54.94^{\mathrm{a}} \pm 0.61$ & $\begin{array}{c}52.25^{\mathrm{a}} \\
\pm 0.66\end{array}$ & $\begin{array}{c}54.07^{\mathrm{a}} \\
\pm 0.58\end{array}$ & $54.07^{\mathrm{a}} \pm 0.61$ \\
\hline OM & $\begin{array}{l}60.64^{\mathrm{a}} \\
\pm 0.64\end{array}$ & $\begin{array}{l}60.20^{\mathrm{a}} \\
\pm 0.63\end{array}$ & $60.42^{a} \pm 0.36$ & $\begin{array}{l}60.75^{\mathrm{a}} \\
\pm 0.88\end{array}$ & $\begin{array}{l}60.00^{\mathrm{a}} \\
\pm 0.57\end{array}$ & $60.3^{a} \pm 0.36$ & $\begin{array}{l}58.5^{\mathrm{a}} \\
\pm 0.57\end{array}$ & $\begin{array}{l}58.85^{\mathrm{b}} \\
\pm 0.64\end{array}$ & $58.85^{\mathrm{b}} \pm 0.36$ \\
\hline $\mathrm{CP}$ & $\begin{array}{l}47.87^{a} \\
\pm 2.04\end{array}$ & $\begin{array}{l}50.57^{\mathrm{a}} \\
\pm 2.22\end{array}$ & $49.21^{a} \pm 1.64$ & $\begin{array}{l}49.35^{\mathrm{a}} \\
\pm 2.07\end{array}$ & $\begin{array}{l}53.80^{\mathrm{a}} \\
\pm 1.92\end{array}$ & $51.56^{\mathrm{a}} \pm 1.64$ & $\begin{array}{l}52.95^{\mathrm{a}} \\
\pm 2.99\end{array}$ & $\begin{array}{l}52.89^{\mathrm{a}} \\
\pm 1.85\end{array}$ & $52.89^{a} \pm 1.64$ \\
\hline CF & $\begin{array}{l}51.48^{\mathrm{a}} \\
\pm 1.19\end{array}$ & $\begin{array}{c}55.70^{\mathrm{a}} \\
\pm 0.55\end{array}$ & $56.27^{\mathrm{a}} \pm 1.1$ & $\begin{array}{l}50.71^{a} \\
\pm 1.33\end{array}$ & $\begin{array}{l}55.30^{\mathrm{a}} \\
\pm 1.12\end{array}$ & $53.59^{\mathrm{a}} \pm 1.1$ & $\begin{array}{l}53.25^{\mathrm{a}} \\
\pm 0.96\end{array}$ & $\begin{array}{c}53.10^{\mathrm{a}} \\
\pm 2.0\end{array}$ & $53.10^{\mathrm{a}} \pm 1.1$ \\
\hline EE & $\begin{array}{l}58.17^{\mathrm{a}} \\
\pm 3.12\end{array}$ & $\begin{array}{l}62.38^{\mathrm{a}} \\
\pm 1.09\end{array}$ & $60.27^{\mathrm{a}} \pm 1.11$ & $\begin{array}{l}60.22^{\mathrm{a}} \\
\pm 0.88\end{array}$ & $\begin{array}{c}62.95^{\mathrm{a}} \\
\pm 1.4\end{array}$ & $61.58^{\mathrm{a}} \pm 1.11$ & $\begin{array}{l}60.42^{\mathrm{a}} \\
\pm 0.64\end{array}$ & $\begin{array}{l}62.18^{\mathrm{a}} \\
\pm 1.35\end{array}$ & $62.18^{\mathrm{a}} \pm 1.11$ \\
\hline NFE & $\begin{array}{c}69.20^{\mathrm{a}} \\
\pm 0.92 \\
\end{array}$ & $\begin{array}{c}63.83^{\mathrm{a}} \\
\pm 0.9 \\
\end{array}$ & $66.51^{\mathrm{ab}} \pm 0.58$ & $\begin{array}{l}70.23^{\mathrm{a}} \\
\pm 0.32 \\
\end{array}$ & $\begin{array}{r}64.69^{\mathrm{a}} \\
\pm 1.21 \\
\end{array}$ & $67.46^{a} \pm 0.58$ & $\begin{array}{c}63.91^{b} \\
\pm 0.84 \\
\end{array}$ & $\begin{array}{c}64.91^{\mathrm{b}} \\
\pm 1.67 \\
\end{array}$ & $64.91^{\mathrm{b}} \pm 0.58$ \\
\hline TDN\% & 66.98 & 67.62 & & 66.98 & 64.05 & & 61.99 & 64.05 & \\
\hline DCP\% & 8.82 & 8.98 & & 8.82 & 8.1 & & 7.88 & 8.1 & \\
\hline
\end{tabular}

- ${ }^{\mathrm{a}, \mathrm{b}}$ Values with different superscripts within a row are significantly different $(P<0.05)$

- DM dry matter, OM: Organic matter, CP: Crude protein, CF: Crude fiber, EE: Ether extract, NFE: Nitrogen free extract, TDN: Total digestible nutrients and DCP: Digestible crude protein.

- G1: No restricted period, G2: $75 \%$ restricted concentrate(30 days post-calving) and G3: $75 \%$ Restricted concentrate (30days pre-calving and30 days post-calving)

Table 3. Effect of different level of feeding during pregnancy on the productive performance of Maghrebi she-camels

\begin{tabular}{|l|c|c|c|}
\hline \multirow{2}{*}{ Items } & \multicolumn{3}{c|}{ Experimental groups } \\
\cline { 2 - 4 } & G1 & G2 & G3 \\
\hline Average initial body weight (Kg/She-camel) & $502.29 \pm 12.89$ & $511.20 \pm 27.05$ & $524.75 \pm 30.25$ \\
\hline Weight before calving (Kg/She-camel) & $551.38 \pm 13.48$ & $559.60 \pm 28.2$ & $566.8 \pm 31.6$ \\
\hline $\begin{array}{l}\text { Total LBW from start to } \\
\text { Before calving (Kg/She-camel) }\end{array}$ & $49.09 \pm 3.54$ & $48.4 \pm 7.42$ & $42.05 \pm 8.30$ \\
\hline Calving weight (kg /She-camel) & & & \\
\hline $\begin{array}{l}\text { Total weight loss before calving and calving } \\
\text { weight (kg/ She-camel) }\end{array}$ & $42.88 \pm 3.57$ & $40.6 \pm 8.37$ & $52.3 \pm 7.49$ \\
\hline Weight after calving(kg) & $521.81 \pm 13.54$ & $527 \pm 28.4$ & $505 \pm 31.75$ \\
\hline Feed intake (kg DM/head/day) & 11.00 & 11.00 & 9.86 \\
\hline Concentrate intake (kg DM/head/day) & 4.54 & 4.54 & 3.40 \\
\hline Roughage intake (kg DM/head/day) & 6.46 & 6.46 & 6.46 \\
\hline Calves birth weight (kg) & $30.44 \pm 0.87$ & $32.8 \pm 1.92$ & $29.73 \pm 2.58$ \\
\hline Calves growth rate after 1 $1^{\text {st }}$ month & $0.326^{\mathrm{a}} \pm 0.56$ & $0.247^{\text {ab }} \pm 0.2$ & $0.176^{\mathrm{b}} \pm 0.09$ \\
\hline
\end{tabular}

- ${ }^{\mathrm{a}, \mathrm{b}}$ Values with different superscripts within a row are significantly different $(P<0.05)$

- G1: No restricted feeding, G2: 75\% restricted concentrate for, 30days post-partum and G3: 60 days $75 \%$ restricted concentrate (30 days pre and 30 days post- partum)

LBW (live body weight), DM(dry matter) 
On the other hand, live body weight changes pre calving to post- calving period showed that there was a great loss in G3 $(52.3 \mathrm{~kg})$ than the two other groups G1 $(42.88 \mathrm{~kg})$ and G2 $(40.6 \mathrm{~kg})$, respectively without significant differences (Table 3 ). This result was in agreement with Safinaze et al (2012) who found that when camels were fed isonitrgenous rations, but with different levels of energy $\left(100,120,140\right.$ and $160 \mathrm{k}$ calorie $\left./ \mathrm{kg}^{0.75}\right)$, the lowest loss in calving weight was in the group which had the higher energy level. Results revealed that calving live body weight indicated insignificant differences among groups.

Changes in live body weights from start to end of experiment are presented in (Table 4). As shown $\mathrm{G} 1$ and $\mathrm{G} 2$ groups indicated higher live body weight $(45.98 \mathrm{~kg})$ and $(35.2 \mathrm{~kg})$, respectively from the start to the end of the experiment, while there was loss in weight by about $(-3.5 \mathrm{~kg})$ for G3 during the same period. The difference among groups were significant $(P<0.05)$. As shown the greatest body weight loss was recorded for G3 which received $75 \%$ of the daily recommended requirement for one month before and another one month after calving, in compare with both of G2 which had $75 \%$ of recommended requirement one month after calving and G1 which received 100\% of the daily requirement .Similar results were reported by Khan et al (2002) who found that there was significant difference in cows body weight from the initial to post calving, where cows in the restricted group lost weight, but the ad libitum group gained weight.

Feed intake pre-calving as DMI were $11.00 \mathrm{~kg}$ for $\mathrm{G} 1$ and $\mathrm{G} 2$ groups, while she-camels received only $9.87 \mathrm{~kg} \mathrm{DMl} \mathrm{/} \mathrm{she-camel/} \mathrm{day,} \mathrm{(Table} \mathrm{3).} \mathrm{The}$ daily intake in the present study was nearly similar to recommendation of Indian Council of Agriculture Research (2013) which was about 10.79 kg/ $\mathrm{DMl} /$ day for pregnant camels.

Values of dry matter intake (DMI) during postcalving period were 11.41 for $\mathrm{G} 1$ and $10.26 \mathrm{~kg}$ /day for G2 and G3 groups (Table 4) and this is nearly similar to the recommendation of Indian Council of Agriculture Research for lactating camels (2013) which was $11.66 \mathrm{~kg}$ DMl head/ day.

Birth weight values of camel calves were 30.44 , 32.8 and $29.73 \mathrm{~kg}$ for G1, G2 and G3 groups, respectively represented in (Table 3 , Fig. 1). As shown there was insignificant effect of restricted feeding periods on camel calves birth weight. These results are in agreement with those of Khan et al. (2002) who pointed out insignificantly differ- ences in calves birth weight between restricted animals and ad libitum group. Similarly Anthony et al (1986) observed also insignificantly effect of low or high plane pre-partum nutrition on calf birth weight, however high plane calves were shown to the slightly heavier than the low plane calves and Safinaze (2012) who found that when camel fed iso-nitrgenous rations and different levels of energy $\left(100,120,140\right.$ and $160 \mathrm{k}$ calorie $\left./ \mathrm{kg}^{0.75}\right)$, there was no significant effect of different level of energy during late pregnancy in dromedary camel on birth weight.

\section{Milk yield}

There were insignificant effect of pre-calving and post-calving restricted feeding periods neither on total milk yield nor daily milk yield during seven months lactation length. Total milk yield values in seven months were $790.05,697.67$ and $708.56 \mathrm{~kg}$, respectively for groups $\mathrm{G} 1, \mathrm{G} 2$ and $\mathrm{G} 3$, respectively, while daily milk yield valued were $3.78,3.32$ and $3.4 \mathrm{~kg} / \mathrm{head} /$ day without significant difference among groups (Table 4). This result disagreed with Khan et al (2002) founded cows on the restricted feeding produced little more milk (3.06 lit/cow/day), than that of the cows on ad. Libitum feeding (2.84 lit/cow/day) during lactation period. Monthly milk yield during seven months are presented in (Fig. 2). The peak of milk yield lies in the third month in G1 and G2 groups while, it delayed in the fourth month in G3 group.Average daily milk in the present study nearly was to that range reported by ElBahey (1982) who found that daily milk yield in Egypt ranged between $3.5-4.5 \mathrm{~kg} /$ day.

\section{Reproductive performance of the dromedary she-camels}

Time required from calving to first heat and time required form calving to conception and were (28.3 and 65.91), (30.8 and 71) and (30.2 and 90.8) days for G1, G2 and G3 groups, respectively (Table 4). There was no significant differences in the time required to first heat among groups, while there were significant $(\mathrm{P}<0.05)$ differences in time required to conception (days), whereas the third group G3 exhibited more longer period to be conceived. It was suggested that, such longer period for G3 to be conceived, was mainly related to the lower nutritional feeding of such group. This was accordance with Musa et al (2006) who found that time from delivery to first heat in dromedary camel 


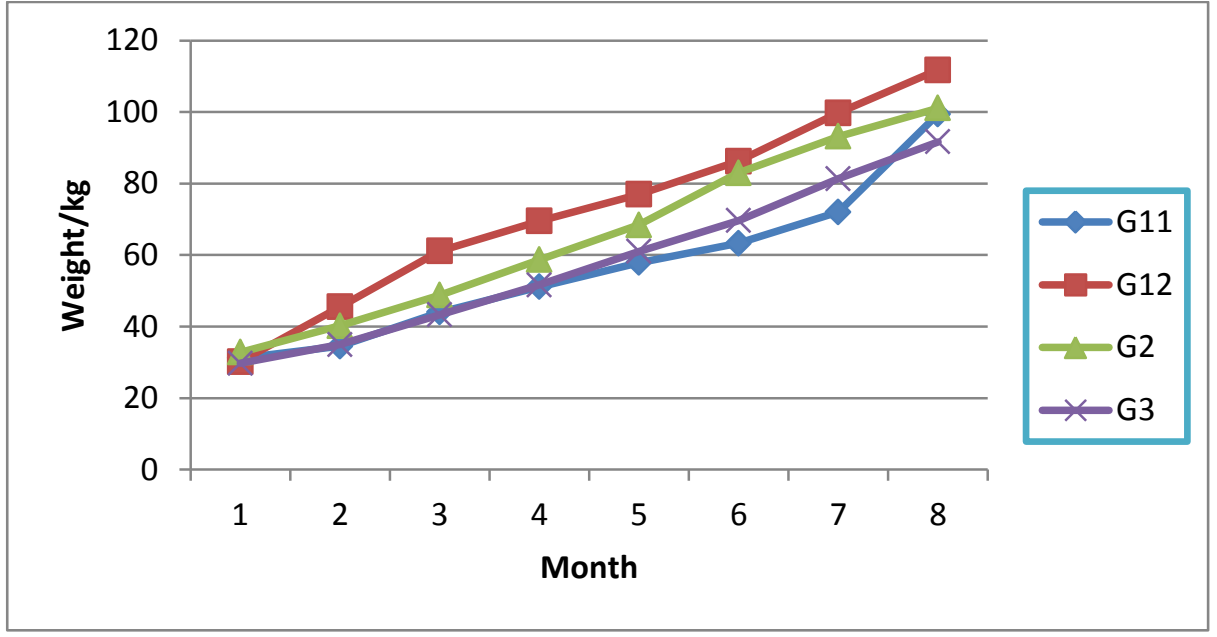

Fig. 1. Weight of the Maghrebi camel calves during experimental period

Table 4. Effect of different of restricted feeding periods on lactation and reproductive performance of Maghrabi she-camel

\begin{tabular}{|l|c|c|c|}
\hline \multirow{2}{*}{ Items } & \multicolumn{3}{c|}{ Experimental groups } \\
\cline { 2 - 4 } & G1 & G2 & G3 \\
\hline Average weight at the end of lactation (kg) & $548.27 \pm 20.8$ & $546.4 \pm 24.01$ & $521.25 \pm 10.02$ \\
LBW changes , (Kg) & $45.98^{\mathrm{a}} \pm 6.29$ & $35.2^{\mathrm{a}} \pm 14.33$ & $-3.5^{\mathrm{b}} \pm 9.52$ \\
(From start to end of experiment) & & & \\
Daily milk yield /She-camel (kg) & 3.78 & 3.32 & 3.40 \\
Total milk yield in seven months (Kg) & $790.05 \pm 47.53$ & $697.67 \pm 31.31$ & $708.56 \pm 58.39$ \\
DMl (day/she-camel) kg & 11.41 & 10.26 & 10.26 \\
Roughage intake (DM/day/she-camel) kg & 6.42 & 6.52 & 6.52 \\
Concentrate intake (DM/day/she-camel)kg & 4.99 & 3.74 & 3.74 \\
Time required to first heat (days) & $28.3 \pm 3.5$ & $30.8 \pm 1.7$ & $30.2 \pm 2.4$ \\
Time required to conception (days) & $65.91^{\mathrm{a}} \pm 17.9$ & $71^{\mathrm{ab}} \pm 20.7$ & $90.8^{\mathrm{b}} \pm 21.5$ \\
\hline
\end{tabular}

- ${ }^{\mathrm{a}, \mathrm{b}}$ Values with different superscripts within a row are significantly different $(\mathrm{P}<0.05)$

G1: no restricted period, G2: 75\% restricted concentrate, 30 days post-calving and G3: $75 \%$ restricted concentrate 60 days(30 days pre-calving and 30 days post-calving) 


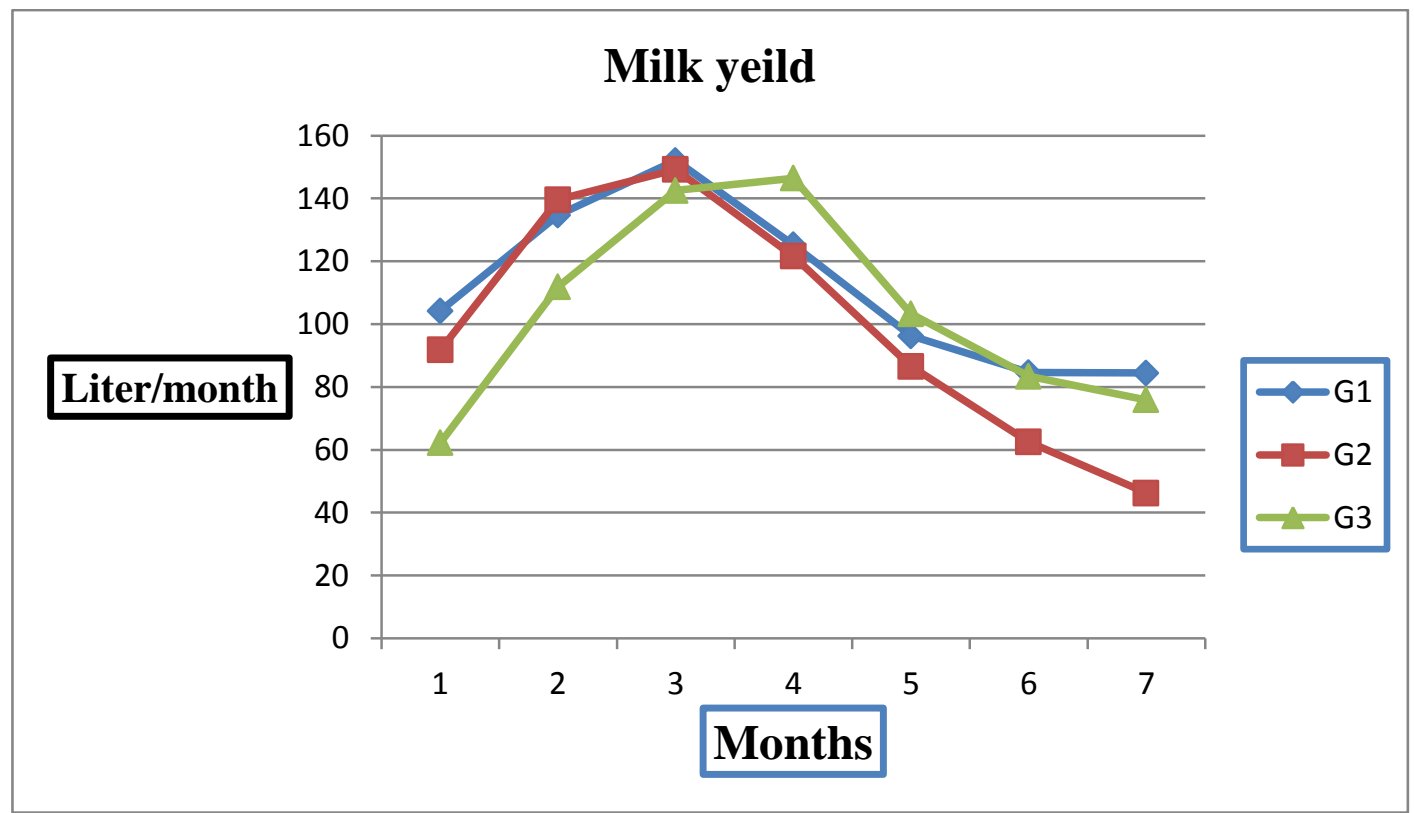

Fig. 2. Milk yield during experimental period

ranged from 30-45 days depending on the nutritional status of animal, while Khan et al (2002) didn't found any significantly effect of nutritional treatment (restriction or ad libitum) on the reproductive performance.

\section{General conclusion and recommendation}

On the light of present study, It could be concluded that, plane of restricted feeding $75 \%$ of daily feed allowances for one month during pre or post-calving didn't lead to any negative effect on the productive performance of she-camel where, there were no effect on live body weight, total milk yield, birth weight of calves and while, reproductive performances of the Maghrebian she-camel there were no effect in time required to first heat but slightly better in time required from calving to conception in group fed on $100 \%$ requirements than other restricted groups. Considerably, all these observation, we can ably this plane of feeding on dromedary she-camel before or after calving, during shortage of feed without any adverse effect of productive or reproductive performance.

\section{REFERENCES}

Abdouli, H. and Kraiem, K. 1990. Effects of chapping length and level and type of protein in supplementation for wheat straw offered ad libitum to camel. Livestock Search for Rural Development, 2, 1-7.

Afaf, H. Zedan 2007. Effect of different periods of feed restriction and realimentation on performance of growing camels. Ph.D. Thesis, Fac. of Agric., Cairo Univ., Egypt. 38 p.

Anthony, R.V., Bellows, R.A., Short, R.E., Staigmiller, R.B., Kaltenbach, C.C. and Dunn T.G. 1986. 1- Effect of pre-partum dietary crude protein on birth weight, blood metabolism and steroid hormone concentration. J. Anim. Sci., 62, 1363-1374.

A.O.A.C. 1990. Association of Official Analytical Chemist. Official Methods of Analysis $15^{\text {th }}$ ed. Washington, DC. USA., pp. 113-140.

Ayoub, M.A. and Saleh, A.A. 1998. Proceeding of the Third Annual Meeting for Animal Production Under Arid Condition 1, 71-87.

El-Bahey G.M. 1982. Normal content of Egyptian camel milk.Vet. Med. J. Egypt 8, 7-10. 
Emad, S.K. 2003. Nutritional studies on beef cattle. M.Sc. Thesis, Fac. of Agric., Cairo Univ., Egypt. pp. 55-72.

Filali, R.Z. and Guerouali, A. 1994. Maintenance energy requirements of the one-humped camel. J. of Arid Enviroments, 26, 3-13.

Garnsworthy, P.C. and Topps, J.H. 1982. The effect of body condition of dairy cows at calving on their food intake and performance when given complete diets. J. Anim. Prod. 35, 113119.

Guerouali, A., Zine Filali, R. and Wardeh, M.F. 1994. Metabolic adjustments of camel during heat stress and dehydration. Proceeding of the 13th Symposium on Energy Metabolism of farm Animals. Majascar, Spain. pp. 15-20.

Guerouali, A. and Wardeh, M.F. 2000. Estimation of energy requirements and microbial protein systhesis at maintenance in sheep and camels fed four levels of intake. Energy metabolism in animals Proceeding of the $15^{\text {th }}$ symposium energy metabolism in animals. EAAP publication No.103. Snekkersten, Denmark, 11-16 September. pp. 7-12.

ICAR 2013. Nutrient Requirements of camel. New Delhi. pp. 12-13.

Khan, M.A.A., Islam M.N., Khan, M.A.S. and Akbar, M.A. 2002. Effect of restricted and ad libitum feeding during late pregnancy on the performance of crossbred cows and their calves. Asian-Aut. J. Anim. Sci., 15(9), 1267-1272.

Khorchani, T., Abdouli, H., Nefzaoui, A. and Hamadi, M. 1992. Nurition of one-humped camel. 2-intake and feeding behavior on arid ranges in southern Tunisia. Anim. Feed Sci \& Tec., 39, 303-311.

Lodge, G.A., Fisher, L.J. and Lessard, J.R. 1975. Influence of prepartum feed intake on performance of cow's fed ad. Libitum during lactation. J. Dairy Sci., 58, 696-702.

Musa, H.H., Shuiep, E.S., Ibtisam El-Zubier, E.M. and Chen 2006. Some reproductive and productive traits of camel ( Camelus dromedaries) in western sudan. J. of Anim. and Vet. Advenced, 5(7), 590-592.
Nabag, M.G., Alatti, K.A. and El-Zubier, I.E.M. 2006. Milk composition of camels and goats grazing in the extensive pasture of Butana area in Sudan. Proceedings of the International Scientific Conference on Camel. Part IV: pp. 2173- 2183. Qassim Univ., Saudi Arabia, 9-11 May 2006.

Nagpal, A.K. and Patil, N.V. 2012. Performance of lactating dromedary camels maintained on different energyrations under arid ecosystem. J. of Camel Practice and Research, 19(2), 229-233.

Reid, J.T., Woolfolk, P.G., Richards, C.R., Kaufamnn, R.W., Loosli, J.K., Turk, K.L., Miller, J.I. and Blaser, R.E. 1950. A new indicator method for determination of the digestibility and consumption of forage by ruminants. J. Dairy. Sci., 33, 60-71.

Robinson, J., Chidzanja, S., Kind, K., Lok, F., Owens, P. and Owen, J. 1995. Placental control of fetal growth. Reprod. Fertil. Dev., 7, 333-344.

Safinaz, M. Shawket, Mohsen, M.K., AbdelRaouf, E.M. and Bakr, A.M. 2012. Nutrient utilization and performance of pregnant camels kept on different levels of dietary energy. Egyptian J. Nutrition and Feeds 15(1), Special Issue, 29-40.

SAS, 2006. SAS User's Guid, Statistical Analysis System Institute Inc. Editors, Cary, NC.

Tygesen, M.P., Nielsen, M.O., Norgaard P., Raving, H., Harrison, A.P. and Tauson, A.H. 2008. Late gestational nutrient restriction: Effects on ewes' metabolic and homothetic adaptation, consequences for lamb birth weight and lactation performance. Arch. Anim. Nutr. 62, 44-59.

Van Keulen, J.V. and Young, B.A. 1977. Evaluation of acid insoluble ash as a natural marker in ruminant digestibility studies. J. Animal. Sci., 44, 282 -289.

Wardeh, M.F. 2004. The nutrient requirements of dromedary camel. J. Camel Sci., 1, 37-50. 